Primljen / Received: 9.5.2013. Ispravljen / Corrected: 27.1.2014. Prihvaćen / Accepted: 19.5.2014. Dostupno online / Available online: 10.7.2014.

\section{Testing and analysis of walls strengthened with FRP}

\section{Authors:}

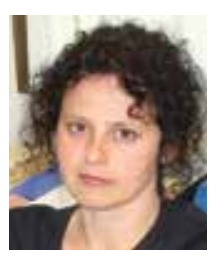

Mojca Jarc Simonič, PhD. CE

Building and Civil Engineering Institute ZRMK mojca.jarc-simonic@gi-zrmk.si

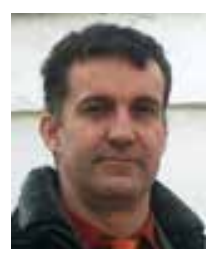

Samo Gostič, PhD. CE

Building and Civil Engineering Institute ZRMK samo.gostic@gi-zrmk.si

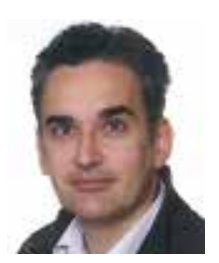

Assoc.Prof. Vlatko Bosiljkov, PhD. CE University of Ljubljana

Faculty of Civil Engineering and Geodesy vlatko.bosiljkov@fgg.uni-lj.si

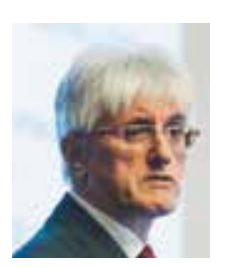

Prof. Roko Žarnić, PhD. CE University of Ljubljana Faculty of Civil Engineering and Geodesy rzarnic@fagg.uni-lj.si

\section{Mojca Jarc Simonič, Samo Gostič, Vlatko Bosiljkov, Roko Žarnić}

Subject review

\section{Testing and analysis of walls strengthened with FRP}

Laboratory and in-situ shear tests of walls strengthened with Carbon FRP (Fiber Reinforced Polymer) strips and Glass FRP grid were compared to the results of different calculation models for masonry with FRP. Tests on new and old solid brick specimens showed an increase in shear strength and ultimate displacement. The best results were obtained with horizontally and horizontally-vertically epoxy-bonded strips and modified cement mortar grid configurations, worse with diagonal strips due to peeling failure. ACl and CNR calculation approaches showed the best agreement with experimental results.

Key words:

masonry, FRP, strengthening, in-situ test, laboratory test, shear strength, calculation models

Mojca Jarc Simonič, Samo Gostič, Vlatko Bosiljkov, Roko Žarnić

Pregledni rad

\section{Ispitivanje i analiza nosivosti na posmik zidova ojačanih s FRP-om}

$U$ radu je opisana usporedba laboratorijskih i terenskih ispitivanja na posmik zidova ojačanih karbonskim (C) trakama i staklenim (G) mrežicama u polimerima s rezultatima proračunskih modela za zidove s FRP-om. Rezultati ispitivanja na zidovima od nove i stare pune opeke pokazali su povećanje posmične nosivosti i graničnog pomaka - najviše za horizontalne i horizontalno-vertikalne epoksidom zalijepljene trake te mrežice u modificiranom cementnom mortu, a najmanje za dijagonalne trake zbog odstupanja sa zida. ACl i CNR računski modeli pokazali su najbolje podudaranje s eksperimentima.

Ključne riječi:

zidovi, FRP, ojačanje, terensko ispitivanje, laboratorijski ispitivanje, otpornost na posmik, proračunski modeli

Übersichtsarbeit

Mojca Jarc Simonič, Samo Gostič, Vlatko Bosiljkov, Roko Žarnić

\section{Versuche und Analysen zur Scherfestigkeit durch FKV ertüchtigten Mauerwerks}

In dieser Arbeit sind Laborversuche und in-situ Tests an durch FKV (Faser-KunststoffVerbund) Streifen aus Kohlenstoff- und Glasfasern ertüchtigtem Mauerwerk mit Resultaten verschiedener Berechnungsmodelle verglichen. Versuche an Proben aus neuem und altem Vollziegel haben einen Zuwachs der Scherfestigkeit und Verschiebungskapazität vorgezeigt, der insbesondere für horizontal und horizontalvertikal mit Epoxid verklebte Streifen und Netze mit Zementmörtel erzielt wurde, während diagonale Streifen dazu neigten abzuschälen. ACI und CNR Berechnungsverfahren haben die beste Übereinstimmung mit den Versuchsergebnissen gezeigt.

Schlüsselwörter:

Mauerwerk, FRP, Ertüchtigung, in-situ Test, Laborversuch, Scherfestigkeit, Berechnungsmodelle 


\section{Introduction}

In order to resist high seismic load, the structural performance of masonry buildings must often be improved by adequate strengthening solutions. Although not every strengthening technique is adequate for the cultural heritage buildings, the FRP strengthening is showing great promise in this field since it is reversible, low weight, it is not time consuming and does not affect the aesthetic of buildings. One of the first attempts to strengthen masonry walls by fibres was made by Croci [1]. He tested shear walls strengthened with vertical and inclined polypropylene strips. Schwegler [2] first proposed the use of CFRP strips for seismic strengthening. He tested diagonal reinforcement with several diagonal strips in each direction on one side or both sides of the wall. Schwegler established linear dependency between the amount of strengthening and shear strength. With regard to the testing of FRP reinforcement (horizontally and vertically placed uni-directional strips), Triantafillou [3] stressed that achievement of the full in-plane strength depends on proper anchorage. Similarly Ehsani [4] reported that the detachment of FRP from the masonry surface is critical. On the contrary, Borri [5] achieved an increase in strength for strengthened panels, without any detachment at diagonal compressive tests. The increase in strength was $55 \%$ for the cement-based mortar, and $240 \%$ for the epoxy adhesive when used for bonding FRP strips. The increase was independent of the type of fibers used (CFRP, GFRP). Valluzi [6] and Santa-Maria [7] performed the one-sided and double-sided FRP strengthening. No increment in shear strength was observed for the one-sided application because the out-of plane flexural failure mechanism prevailed. The double-sided diagonal reinforcement was more effective where the shear strength increased by $70 \%$. Alcaino [8] and Gostič [9] showed that the diagonally retrofitted masonry walls had a brittle failure with sudden loss of strength due to detachment of FRP, while the failure was less brittle in case of horizontally retrofitted walls. The problem of sudden strength loss decreased with better distribution of CFRP reinforcement. Researchers from the Faculty of Civil Engineering Zagreb (Galić [10], Španić [11]) tested GFRP reinforced specimens in the horizontal-diagonal and the horizontal-vertical configurations. An increase in strength achieved with a combination of horizontal and vertical strips was $86 \%$, while it amounted to $83.5 \%$ for a combination of horizontal and diagonal strips. ElGawady [12] performed strengthening of cracked specimens. The FRP retrofitting technique was effective in significantly increasing the inplane strength, stiffness and deformability of URM walls. Papanicolaou [13], Triantafillou [14] and Tomaževič [15] achieved an increase in strength by coating the surface with FRP grids or fabrics. The failure mechanism in these cases was a shear failure with detachment of coating from the wall surface.
The review of test results provided by various authors shows that different configurations of the strengthening, material characteristics and geometry of masonry walls have a codependent effect on the shear strength and the mode of failure of the FRP reinforced walls subjected to an in-plane shear force. The results can therefore vary to a great extent. As it was established that detachment of strips is a common problem of FRP reinforcement glued to the surface, the solution to avoid detachment of strips with wrapped strips was tested to avoid this problem. The hypothesis was that an important advantage can be achieved by using horizontal strips instead of diagonal strips- the former can be placed as a confinement around the wall and therefore a brittle failure due to detachment can be avoided. Narrow strips were chosen because of lower material costs and easier on-site application. Their advantage lies in the fact that they can be installed around walls without removing neighbouring windows or doors. In order to confirm this hypothesis, different types of horizontal confined CFRP strips configurations were applied on the old and new walls. The new solution was compared to un-strengthened walls and other different ways of shear strengthening of masonry walls: diagonal strengthening and grids applied on the entire surface. We established an increase in in-plane strength and ductility of URM (Unreinforced masonry) walls when strengthened - which is similar to the above stated tests. However, unlike Schwegler, we found no linear dependency between the amount of strengthening and the shear strength. The importance of proper anchorage for achieving full in-plane strengthening effect was recognised by several authors, and is also evident from our tests. The purpose of this scientific research is to endorse the implementation of newly developed technologies in general construction practice. Therefore analytical models have to be set for the design purposes. The existing calculation models might be too specific (applicable only to certain configurations) or might not be accurate enough for a particular range of material characteristics. A comparison between the experimental results and the five existing calculation models was performed in this paper in order to evaluate accuracy of individual procedures. Triantafillou [16] presented one of the first calculation models for determining the strength of the FRP strengthened walls. It is applicable only for horizontally or vertically strengthened walls, or for a combined strengthening. Wang [17] provided a calculation model for horizontal and inclined configurations, which proved to be very accurate for the large set of experimental data they analysed. The calculation model presented by Marcari [18] was developed for diagonal reinforcement. We made a comparison of these with two code recommendations: CNR-DT 200/2004 [19], and ACl 440.7R-2010 [20]. The results of the calculations are compared to experimental results in Section 4.6.

\section{Experimental program}

The seismic performance of most critical elements of masonry to fail in shear during an earthquake - parts of walls 
between openings - was tested. Different CFRP placement configurations were set: horizontal strips (wide or narrow, in combination with or without vertical strips), and diagonal strengthening. In addition, the strengthening with GFRP grid embedded in ductile modified cement mortar over the entire surface was tested. The shear testing of walls with a vertical pre-compression load was conducted both in laboratory and in-situ conditions (on two different buildings). Characteristics of basic materials (brick, mortar and FRP fabric) were determined by standard testing in laboratory.

Laboratory tests on new brick walls were performed first (Gostič [9]). Diagonally placed strips, as they are oriented in the direction of highest tensile stresses (lab D in Figure 1), and two types of the horizontal confined CFRP strips configurations, were used. The horizontal and vertical configurations (lab HV in Figure 1) had horizontal strips $15 \mathrm{~mm}$ in width, with bended ends around the edges, confined with vertical strips on the side. The strips were evenly distributed, with two strips in the middle of the wall height, where the maximum shear crack occurred in non strengthened walls. For the horizontal configuration (lab $\mathrm{H}$ in Figure 1), horizontal strips were wrapped around the wall with an overlapping bond. The wrapped strips were placed in the area subjected to highest loads, from the middle height to the fixed end. At fixed end, the strips were concentrated to postpone toe-crashing observed in a previous investigation on $H V$. At the (cantilever) free end, the forces were low, and so this area was left un-strengthened.

The confinement around brick walls during laboratory testing turned out to be very promising. A similar reinforcement of brick walls was selected for the experiments in-situ (Figure 2). Since diagonal reinforcement showed poor improvement in shear strength during laboratory tests, and as the masonry was weaker, the width of strips was doubled to $100 \mathrm{~mm}$ for the in-situ diagonal testing (see D in Figure 2). We also used the same wider strips for the horizontal reinforcement. Although laboratory tests with narrow strips showed good performance, the draft calculation for in-situ weak walls showed a low increment, and so the decision was made to use wider strips. We selected $100 \mathrm{~mm}$ strips (for diagonal reinforcement) placed at each fixed end where toe-crashing could occur, and in the middle of the specimen (for the upper and lower parts), where tensile stresses are the greatest (see $\mathrm{H}$ in Figure 2). We combined horizontal with vertical strips to postpone occurrence of first cracks in the corners of the panel due to wall bending. For diagonal configuration, it was assumed that the vertical strips were not needed because the capacity against rocking mechanism would be assured by the anchoring length $(200 \mathrm{~mm}$ ) of diagonals. During tests on the first building, a delamination was observed in the case of vertical strips and diagonals, and so they were not used in the final test configuration. In-situ tests on the second building (Figure 3) were performed on the walls strengthened with narrow $15 \mathrm{~mm}$ wide horizontal strips (C-S), placed similarly at the ends of each upper and lower part of the wall to postpone toe-crushing, and in the middle to postpone shear diagonal cracking. The last strengthening configuration (C-M) was done for the shear reinforcement with GFRP grids embedded in ductile modified cement mortar over the entire surface. The hypothesis was that the higher load bearing capacity of the URM masonry wall could be reached with lower cost of the strengthening material (glass instead of carbon fibres, modified cement mortar instead of epoxy glue). Also the ductility of the retrofitting system FRP-masonry might be improved due to a more ductile mortar (compared to epoxy) and larger surface covered. This might lead to subsequent detachment of the coating.

\subsection{Laboratory tests}

Sixteen walls (height / width / thickness $=1.26 / 1.06 / 0.12 \mathrm{~m}$ ) made of contemporary solid clay brick $(250 \times 120 \times 65 \mathrm{~mm})$ were built and tested at the Materials and Structures Laboratory of the University of Ljubljana. The mortar used was a mixture of cement, lime and sand $\left(D_{\max }=4 \mathrm{~mm}\right)$ in a volume ratio of 1:2:6. They were erected on a reinforced concrete base footing. All specimens were cured for at least one year before testing. The walls were strengthened with unidirectional carbon fibres in different configurations; six with $50 \mathrm{~mm}$ wide diagonal strips (marked as lab D), three (lab H) with horizontal narrow $15 \mathrm{~mm}$ wide strips at five levels, and three (lab HV) with horizontal narrow $15 \mathrm{~mm}$ wide strips at nine levels, and 50 $\mathrm{mm}$ wide strips at the sides. The strips were applied at the front and back sides, or wrapped in the case of horizontal only strips. The weight of CFRP was $800 \mathrm{~g} / \mathrm{m}^{2}$. Four walls were left unreinforced (marked as lab $P$ in Figure 1). The specimens were compressed vertically with $400 \mathrm{kN}$, which amounted to approximately $25 \%$ of the masonry compressive strength. The wet lay-up technique was used to apply CFRP to the wall. The walls were cleaned by abrasion. An epoxy primer was applied first to ensure better adhesion. The CFRP was bonded to the surface of the wall with an epoxy adhesive, combined with filler. Finally the top coat of epoxy adhesive was applied to ensure saturation of the fabric.

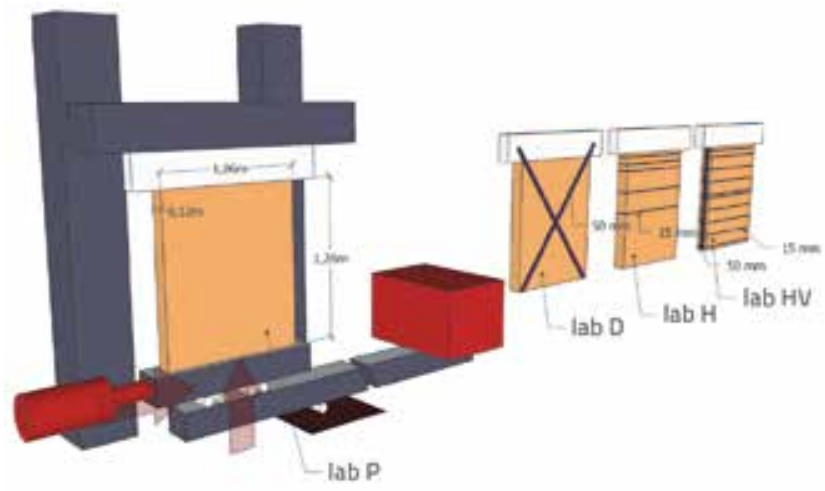

Figure 1. Configurations of strips and set-up for laboratory shear tests 


\subsection{In-situ tests}

The in-situ tests were performed on two typical old masonry buildings (Gostič [21], Jarc Simonič [22]). One was built in 1930's, in Maribor (MB), and the other was erected in 1874 in Cirkovce (C). The load bearing masonry walls were made of solid clay bricks $(295 \times 140 \times 65 \mathrm{~mm}$ and roughly $300 \times 120$ $\times 60 \mathrm{~mm}$ for $\mathrm{MB}$ and $\mathrm{C}$, respectively) and weak lime mortar. These materials are common for cultural heritage buildings from that period. Wall thicknesses in the MB building are: 0.30 $\mathrm{m}$ and $0.45 \mathrm{~m}$. Three specimens were taken for each thickness one unreinforced specimen (marked with o), one strengthened specimen with diagonal strips (D), and one with the combined horizontal and vertical strips ( $\mathrm{H}$ in Figure 2).

Masonry walls of the building $\mathrm{C}$ were $0.52 \mathrm{~m}$ in thickness. Six undamaged specimens were isolated. Two were reference unreinforced specimens (marked as R), two were strengthened with narrow horizontal strips (S), placed on specimens in 10 levels, and two with GFRP grid (M) placed over the entire surface (Figure 3 ).

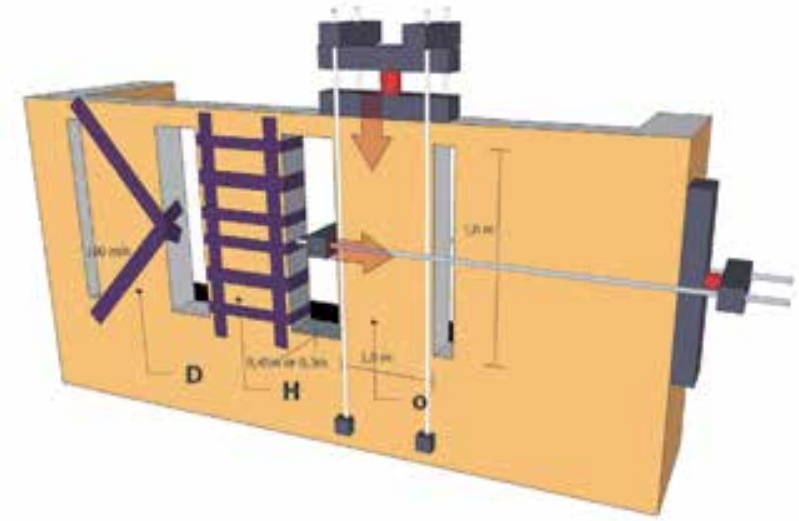

Figure 2. Configuration test set-up for in-situ shear tests (MB building)

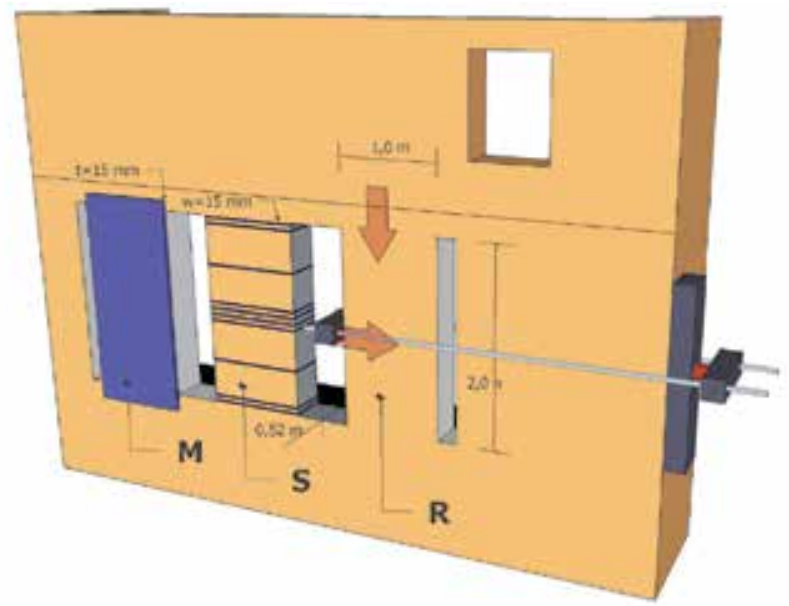

Figure 3. Configuration test set-up for in-situ shear tests (C building)

The specimens were cut with wire saw to ensure low, undamaging vibrations and smooth sides $1.0 \mathrm{~m}$ in width, and
$2.0 \mathrm{~m}(\mathrm{MB})$ and $2.1 \mathrm{~m}(\mathrm{C})$ in height. CFRP strips and GFRP grids were glued onto the surface after removal of plaster, grinding of loose parts, and rounding of edges where needed to avoid cracking of CFRP fibres because of the bending. Surface unevenness was corrected with cement mortar up to $5 \mathrm{~mm}$ in thickness.

The wet lay-up technique was used to apply CFRP to the wall. They were bonded with epoxy resin on both sides of the masonry or wrapped around the walls. In MB, CFRF strips were $100 \mathrm{~mm}$ in width and $300 \mathrm{~g} / \mathrm{m}^{2}$ in weight. In C, strips were $15 \mathrm{~mm}$ in width and $800 \mathrm{~g} / \mathrm{m}^{2}$ in weight. Horizontal strips were glued one (in-situ MB) or two (in situ C) in each of the compression loaded areas, and one in the middle of each half of specimen. Diagonal strips were glued only on the 'tensile' diagonal of the wall as the load set-up enabled only one direction for applying horizontal force. The GFRP grid was laid into the modified cement mortar $15 \mathrm{~mm}$ in average thickness. The basic information about the existing masonry, compressive strength, and modulus of elasticity, was determined via in-situ compression tests.

A constant vertical load was applied during the in-situ shear test, which resulted in the stress of roughly $10 \%$ of the masonry compression strength (for C-S the load was $67 \mathrm{kN}$, C-M: 65 kN, MB30: 65 kN, and MB45: $95 \mathrm{kN}$ ). A preload had to be applied for the MB in-situ tests to simulate a two storey building. No preload was applied for the $C$ building in-situ tests as this building was two storeys high, with the ground floor and first floor, each $3.2 \mathrm{~m}$ in height.

\subsection{Test protocol}

In laboratory tests, the walls were tested as cantilevers in the test frame (Figure 1). The free end was at the bottom of the test frame, where vertical and horizontal loads are transmitted onto the specimen. For in-situ tests the horizontal load of the hydraulic actuator (1000 kN) was applied in the middle of the wall height for each prepared panel, separating it into the top and bottom 'specimens'. The horizontal load from the hydraulic actuator was distributed half to the bottom part of the wall and half to the top part. The forces acting on two halves of the wall were thus assumed to be identical but the deformations were different (as measured, cf. Figure 7 and Figure 8). The specimens were thus tested as elements with the ends symmetrically fixed into the surrounding masonry. During the laboratory testing, the horizontal loading increased in steps of $0.5 \mathrm{~mm}, 1.0,2.0,4.0 \mathrm{~mm}$, etc., with each loading step repeated cyclically three times with the same amplitude and velocity (Figure 4). The shear loading was provided by the displacement controlled servo-hydraulic actuator 250 $\mathrm{kN}$ in capacity. The actuator was fixed to the supporting frame. During the in-situ tests, the loading was displacement controlled and was progressing with one repetition to the step (to $0.5 \mathrm{~mm}, 1.0,1.5,2.0,3.0 \mathrm{~mm}$, etc) and release near zero (Figure 5). The loading was stopped when the lateral force in 

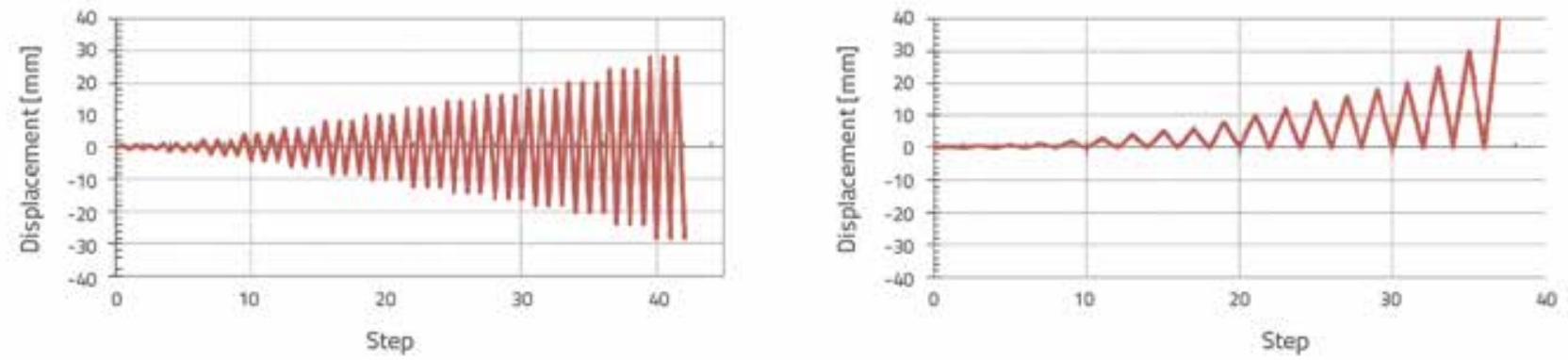

Figure 4. Loading protocol in lab tests

Figure 5. Loading protocol for in-situ tests

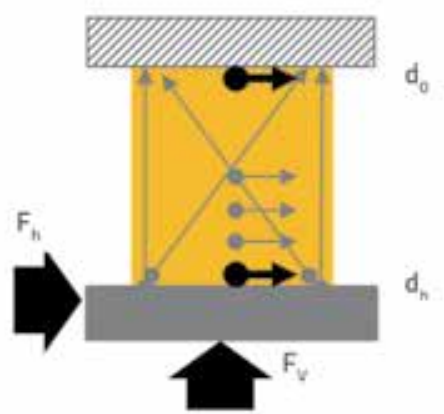

Figure 6. Measurement points for tests in laboratory $(P, D, H, H V)$

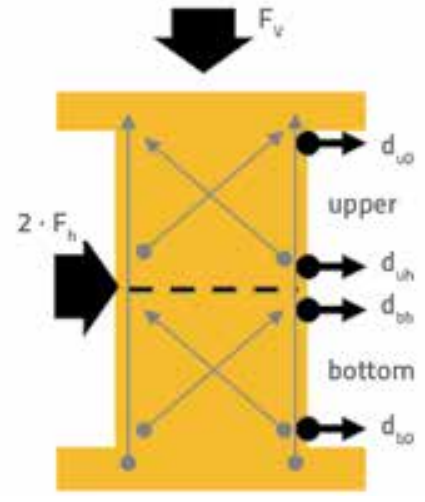

Figure 7. Measurement points for in-situ tests $\mathrm{O}, \mathrm{D}$ and $\mathrm{H}$

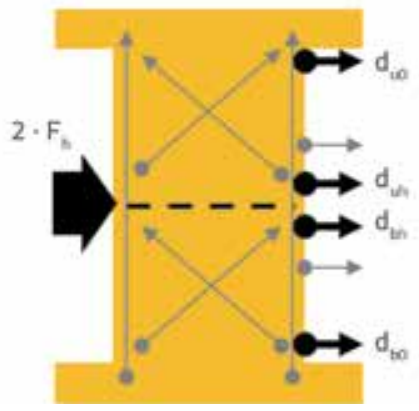

Figure 8. Measurement points for in-situ tests $\mathrm{R}, \mathrm{S}$ and $\mathrm{M}$ the current step could not reach $80 \%$ of the maximum force already achieved in the test.

In all three test cases, the horizontal displacements and deformations were measured with linear variable differential transducers (LVDTs). Masonry deformations were also measured using LVDTs attached diagonally and vertically along the height of the wall. Load cells were used to measure vertical (prestress) and horizontal load. Typical set-up for the measurement instruments can be seen in figures below (Figure 6 to Figure 8) where the most important measurements relevant to this paper are stressed in bold (applied forces and displacements).

\subsection{Materials}

Standard laboratory tests of constituent materials, aimed at determining the compressive strength of brick and mortar, tensile strength of FRP fabric, and some other characteristics listed in the table below, were performed in parallel with the main shear tests. The characteristics of the in-situ and laboratory masonry were considerably different. Contemporary materials and careful mason work (especially the use of better mortar) when building laboratory specimens resulted in 15-times higher compressive strength and 9-times higher elastic modulus than in the case of the old masonry tested in-situ.

Table 1. Mechanical characteristics of materials

\begin{tabular}{|l|l|c|c|c|c|}
\hline \multirow{2}{*}{ Material } & Property & Laboratory & In situ (Maribor) & In situ (Cirkovce) & Method \\
\hline \multirow{2}{*}{ Brick } & Compressive strength & $32 \mathrm{MPa}$ & $20,1 \mathrm{MPa}$ & $6,5 \mathrm{MPa}$ & EN 772-1:2000 \\
\cline { 2 - 6 } & Tensile strength & $5,34 \mathrm{MPa}$ & - & - & EN 1015-11:1999 \\
\hline \multirow{2}{*}{ Mortar } & Compressive strength & $6,77 \mathrm{MPa}$ & $\sim 0,5 \mathrm{MPa}$ & $\sim 0,5 \mathrm{MPa}$ & - \\
\cline { 2 - 6 } & čvrstoća savijanja & $2,08 \mathrm{MPa}$ & - & $3400 \mathrm{MPa}^{*}$ & ASTM D 3039/D 3039M \\
\hline \multirow{2}{*}{ CFRP } & Tensile strength & $3400 \mathrm{MPa}$ & $3800 \mathrm{MPa}^{*}$ & $230 \mathrm{GPa}^{*}$ & \\
\cline { 2 - 6 } & Young's modulus & $230 \mathrm{GPa}$ & $240 \mathrm{GPa}^{*}$ & $75 \mathrm{GPa}^{*}$ & \\
\hline GFRP grid in mortar & Young's modulus & & & & \\
\hline *data was taken from manufacturer's declaration & & &
\end{tabular}


Table 2. Compression test results for masonry

\begin{tabular}{|c|c|c|c|c|}
\hline Material & Property & Laboratory & In situ (Maribor) & In situ (Cirkovce) \\
\hline \multirow{4}{*}{ Masonry } & Compressive strength & $12,4 \mathrm{MPa}$ & $1,92 \mathrm{MPa}^{*}$ & $1,45 \mathrm{MPa}^{*}$ \\
\hline & E (Young's modulus) & $5,74 \mathrm{GPa}$ & $0,64 \mathrm{GPa}$ & $0,77 \mathrm{GPa}$ \\
\hline & $v$ (Poisson's ratio) & 0,12 & 0,49 & - \\
\hline & G (shear modulus**) & $2,29 \mathrm{GPa}$ & 0,21 GPa & $0,30 \mathrm{GPa}$ \\
\hline \multicolumn{5}{|c|}{$\begin{array}{l}\text { * compressive strength calculated from the masonry tensile strength (obtained by Brazilian splitting test) } f_{m c}=10 f_{m t}, f_{m t}=2 F_{v} /(\pi L H) \text { and } L \text { is } \\
\text { the length of specimen, and } H \text { is the height of specimen }[23]) \\
\text { ** shear modulus of masonry is calculated as } G=E /(2(1+v)) \text { from compression test results }\end{array}$} \\
\hline
\end{tabular}

\subsection{Compression tests}

Specimens for the in-situ compression tests on brick wall samples were prepared by cutting out the wall using wire saw. The tests were performed to determine the compressive strength and modulus of elasticity. Dimensions of the specimen for in-situ test C were (length/height/thickness) $1.00 \times 1.00 \times 0.48 \mathrm{~m}$. Two specimens were prepared for the in-situ test $\mathrm{MB}$, one in the $0.30 \mathrm{~m}$ thick wall (length/height/ thickness) $1.00 \times 1.00 \times 0.30 \mathrm{~m}$, and one in the wall $0.45 \mathrm{~m}$ in thickness $1.00 \times 0.85 \times 0.45 \mathrm{~m}$. Laboratory specimens were built with dimensions $0.50 \times 0.50 \times 0.12 \mathrm{~m}$. Three were unstrengthened, and three strengthened with $15 \mathrm{~mm}$ wide CFRP strips as confinement around both end rows and the middle one. In-situ compression tests were carried out with a hydraulic actuator of 1300 kN capacity, and laboratory tests were conducted with a hydraulic actuator of $5000 \mathrm{kN}$ capacity. For in-situ tests, vertical and horizontal deformations were measured with LVDTs mounted on one side of the wall (two verticals and one horizontal), while for laboratory tests they were applied on both sides of the walls. Due to imperfections of the testing equipment (steel profile for vertical load distribution was narrower than the wall thickness by about $0.1 \mathrm{~m}$ ) the final failure of the in-situ masonry was more due to splitting than to pure compression. A more realistic compressive strength was then obtained considering the tensile strength evaluated with the formula for the Brazilian splitting tensile test, and an assumption that compression strength is about 10 times the tensile strength by splitting (Bosiljkov, [24]). Mechanical characteristics obtained in this way with the compression tests are presented in Table 2.

\section{Shear test results}

The hysteresis response and the envelopes of results for different configurations of strengthening are compared in diagrams (Figures 9, 11, and 14). The results were collected as averages for 'positive' and 'negative' directions of forced displacement in the case of laboratory tests (averages were calculated for the horizontal force and displacements). In the case of in-situ tests the average was calculated from the measured displacements of the lower and upper parts of the wall, while the measured force was divided equally (as it is supposed to be acting) between the upper and lower specimens (see Figure 7). The rotation was calculated from horizontal displacements divided by the height of specimens. Configurations $\mathrm{R}, \mathrm{M}$, and $\mathrm{S}$ were tested on two specimens (marked $\mathrm{a}$ and b) both $0.52 \mathrm{~m}$ in thickness. Configurations $\mathrm{O}, \mathrm{D}$ and $\mathrm{H}$ were each tested on the walls 0.30 $\mathrm{m}$ and $0.45 \mathrm{~m}$ in thickness. The effectiveness of different FRP strengthening configurations is presented in "load bearing" (Figures 10, 12, and 15) and "rotation capacity" (Figures 10, 13 and 16) diagrams, where they are compared to reference unstrengthened samples of each test set-up.

Due to better materials used and careful workmanship, the specimens prepared and tested in the laboratory yielded much higher shear load bearing capacities (from 0.7 to $1.0 \mathrm{MPa}$ ) compared to old masonry on the site (from 0.1 to $0.2 \mathrm{MPa}$ ).

The biggest increase in shear strength (up to $170 \%$ ) was obtained by horizontal strengthening of the (weak) walls on site, while the effect of horizontal strengthening on laboratory walls was $120 \%$. The highest increase ( $380 \%$ ) of ultimate rotation can be observed for horizontal (and vertical) CFRP strips applied to masonry on site, and it was also high (around $200 \%$ ) for configurations $\mathrm{H}$ and $\mathrm{HV}$ tested in the laboratory.

Compared to un-reinforced specimens, which typically failed by diagonal tensile mechanism, the crack propagation was efficiently obstructed by the CFRP strips confining the masonry, which resulted in formation of many minor shear cracks. Horizontal FRP strips did not detach from the surface because they were well connected around the masonry pier. In the laboratory, the failure mode started as a combination of the shear and flexural modes. The first cracks occurred in the corners of the panel due to the rocking of the wall. The predominant mode of failure for the type $(\mathrm{H})$ and $(\mathrm{HV})$ strengthening was flexural mode, which resulted in a local failure of the wall compressive toe (Figure 19b).

Some local detachments of vertical strips from the surface appeared at the $\mathrm{H}$ configuration of the in-situ MB test (strips $100 \mathrm{~mm}$ in width), although all horizontal strips remained undamaged until the end of the experiments (Figure $19 \mathrm{~d}$ ). The failure mechanism was governed by diagonal (shear) cracking of the masonry which was to some extent obstructed by FRP strips.

The diagonal configuration contributes to a minor extent to the shear strength $(\sim 5 \%)$, and with about $10 \%$ to the ultimate rotation. FRP strips in diagonal configuration on site detached on uneven parts of the masonry surface, where the weakest part 


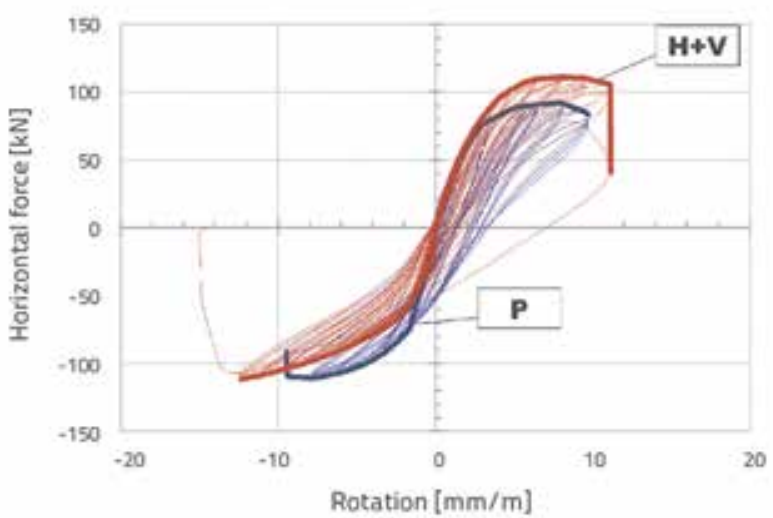

Figure 9. Hysteresis and envelopes for laboratory shear tests of configurations: P (pure-reference) and HV (horizontal with vertical strips)

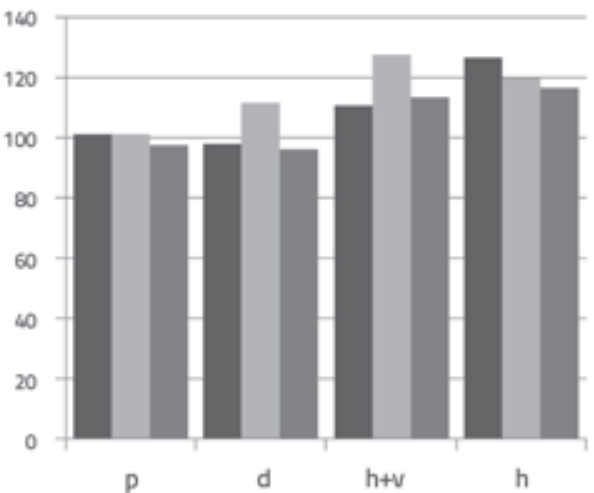

Figure 10. Results of laboratory tests for load bearing effectiveness: $D, H$ and HV compared to un-strengthened wall (p); for all three specimens (i, ii, and iii)

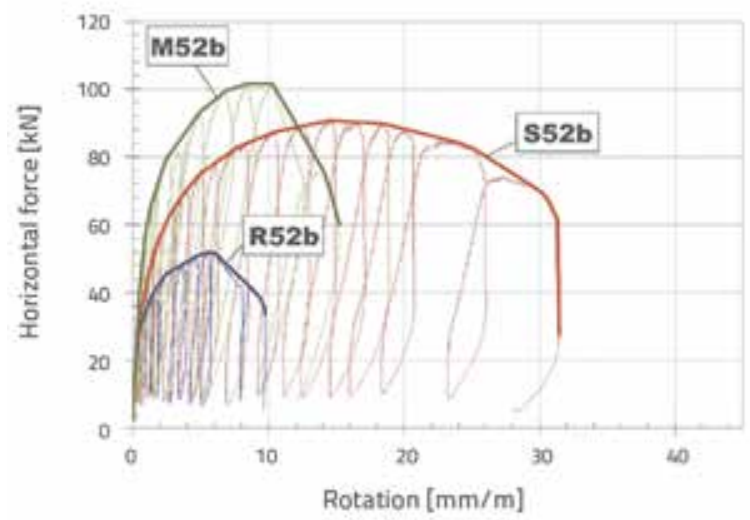

Figure 13. Hysteresis and envelopes for in-situ shear tests of FRP strengthening configurations: $M$ (mesh), $\mathrm{S}$ (strips) and R (reference)

(where the detachment was initiated)was in the brick. Diagonally strengthened walls in the laboratory showed flexural and diagonal crack development. Toe crushing was the main cause of failure for this type of strengthening during the 'lab D' tests.

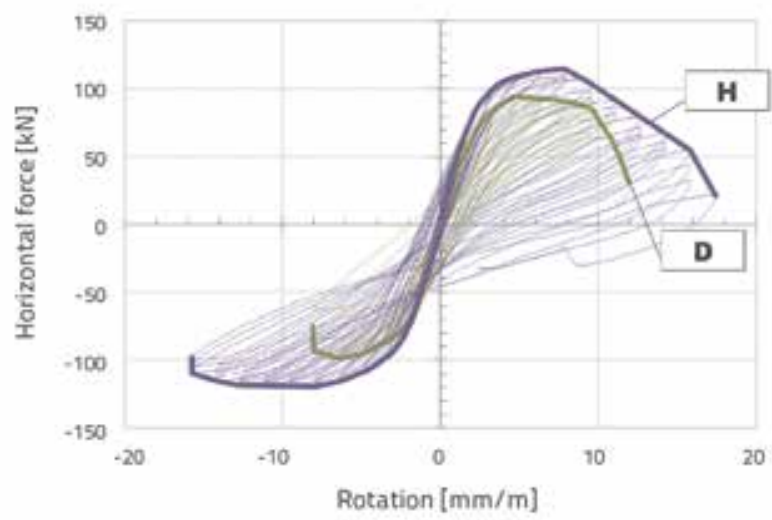

Figure 11. Hysteresis and envelopes for laboratory shear tests of CFRP strengthening configurations: $D$ (diagonal) and $\mathrm{H}$ (horizontal)

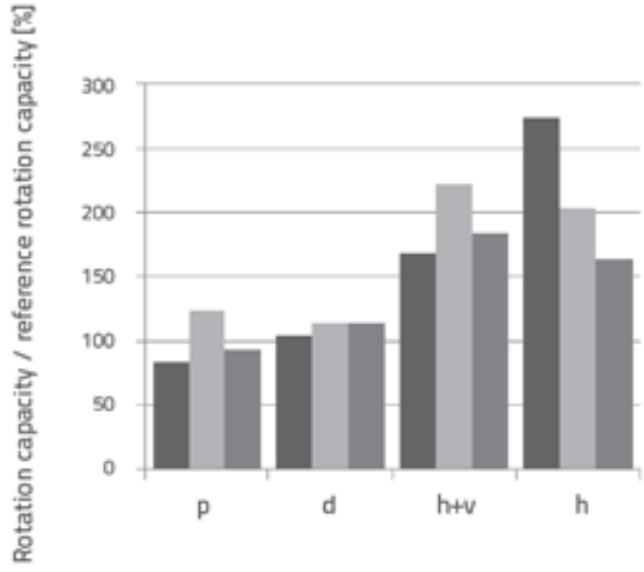

Figure 12. Rotation capacity of different FRP configurations tested in laboratory: D, H and HV compared to un-strengthened wall (p)

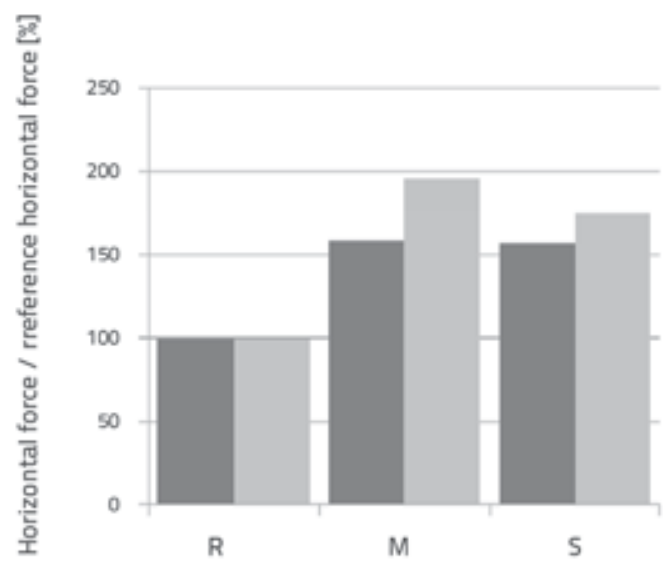

Figure 14. Results of in-situ tests for load bearing effectiveness of FRP strengthening ( $M, S$ vs. R)

The load bearing capacity for the in-plane shear stresses almost doubled in case of the GFRP grid in modified cement mortar, although it behaved in the non-ductile manner, with similar ultimate displacement as the URM specimen. 


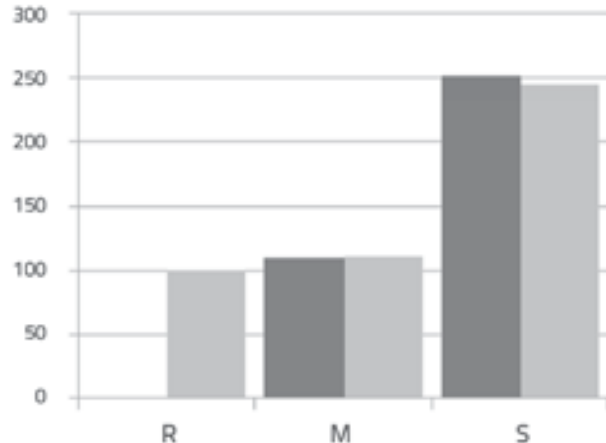

Figure 15. Results of in-situ tests for rotation capacity of (M, S vs. R)

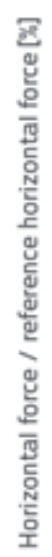

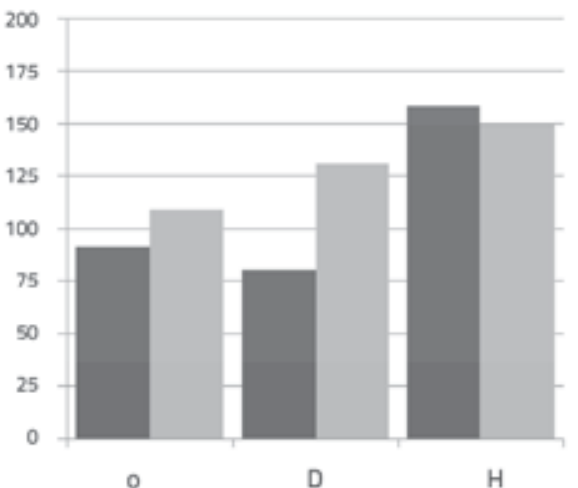

Figure 17. Results of in-situ tests for load bearing effectiveness of FRP strengthening ( $D, H$ vs. o)

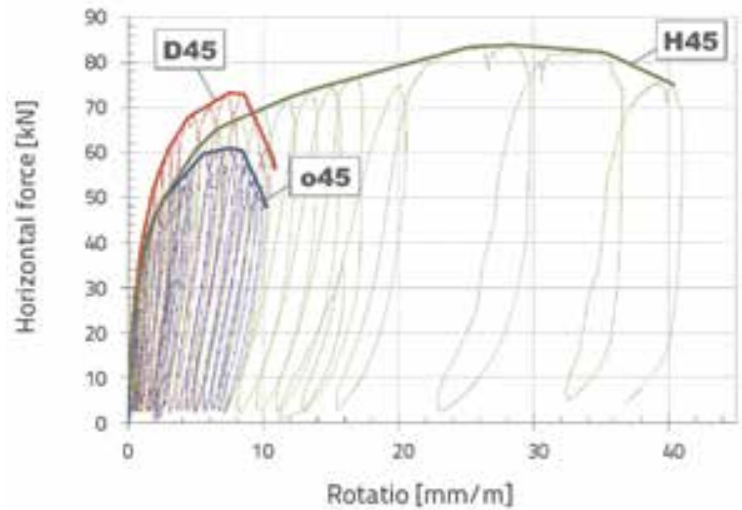

Figure 16. Hysteresis and envelopes for in-situ shear tests of CFRP strengthening configurations: $\mathrm{D}$ (diagonal), $\mathrm{H}$ (horizontal), $\mathrm{O}$ (un-strengthened

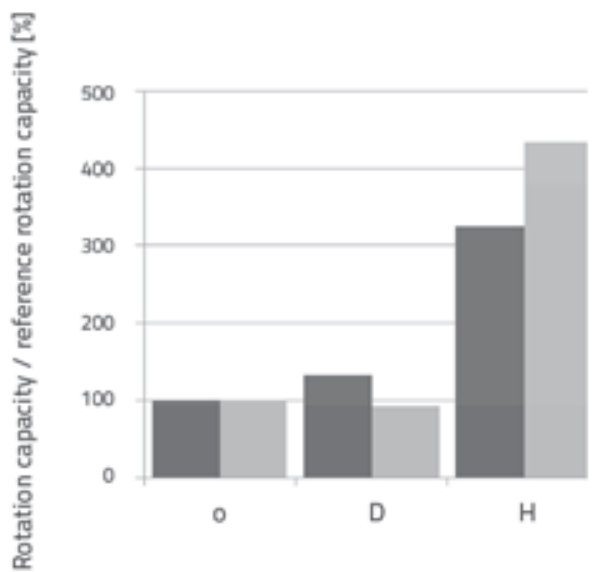

Figure 18. Results of in-situ tests for rotation capacity of (D, H vs. o)

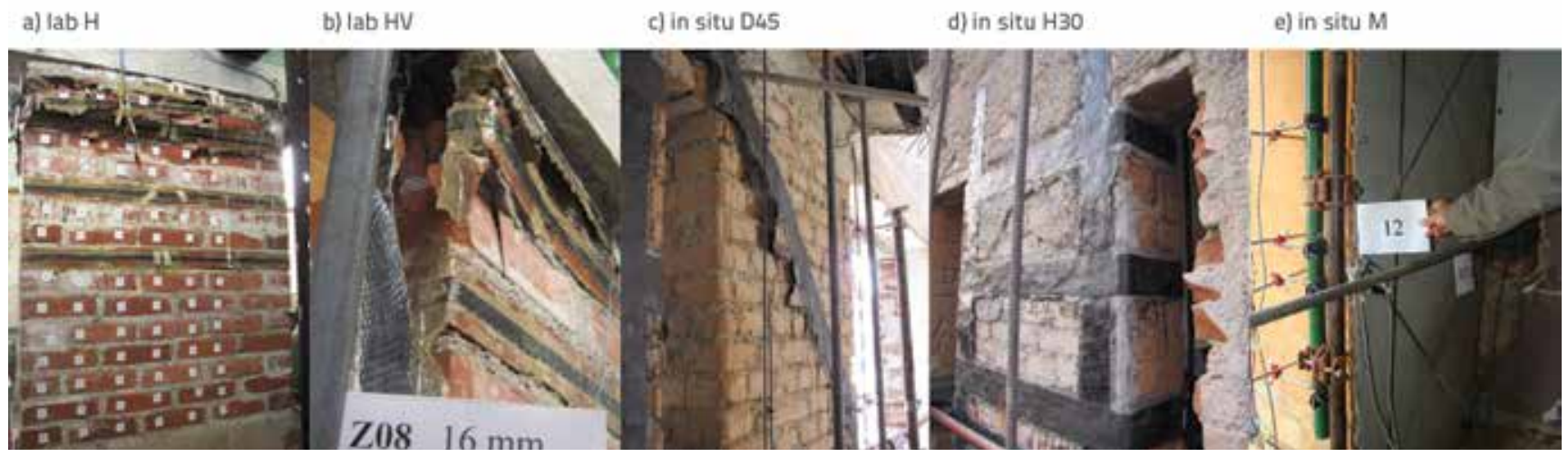

Figure 19. Failure modes of FRP reinforced masonry observed during testing

The failure mechanism was shear failure with detachment of the GFRP reinforced plaster from the wall surface. The detachment mostly propagated in compression zones.

From the results of our tests, we can conclude that the reinforcement provided solely with the CFRP glued in a diagonal direction of the wall is not an effective solution. For the laboratory and in-situ tests, the effect of horizontal strips confining the wall was decisive for higher load bearing capacity, and especially for higher ultimate rotation capacity.

\section{Design considerations}

Various calculation models for the design of FRP strengthened masonry walls, as well as appropriate guides, have been 
developed over the past two decades (Garbin [24], Prota [25], Zhuge [26], Myers [27], Nardone [28], etc). Several design models were taken under consideration in this paper to determine how they approximate to the experimental results. Our horizontal, horizontal-vertical, and grid configurations were evaluated by American ACl 440.7R-10 Guide for the Design and Construction of Externally Bonded Fiber-Reinforced Systems for Strengthening Unreinforced Masonry System (2010), Italian Guide for the Design and Construction of Externally Bonded FRP Systems for Strengthening Existing Structures (CNR-DT 200/2004), and calculation models set by Wang [17], Triantafillou [16], and Marcari [18]. Wang and Marcari formulas were used for the evaluation of strengthening with diagonal CFRP strips.

The total shear load of the strengthened specimens is the sum of two components: the shear load of the unreinforced masonry wall, and the shear load contribution of the FRP strengthening. There are differences in calculation of shear capacity of the unreinforced masonry wall, as well as in definition of the FRP contribution. For the URM (unreinforced masonry) design, the bed joint sliding (Triantafillou, ACl, CNR, Wang), diagonal tension failure ( $\mathrm{ACl}$, Wang, Marcari) and toe-crushing (Triantafillou, $\mathrm{ACl}$, CNR) were taken under consideration. The FRP contribution was calculated through the truss mechanism, based on detachment failure. Dependant on experimental data or the analytical/ numerical model, the $\varepsilon_{\text {frp_e }}$ is limited to the value where the bond behaviour of FRP system and masonry substrate are not sufficient to transmit shear forces. Limitations are set as different coefficients. Triantafillou [3] model adopted formula for effective strain $\varepsilon_{\text {frp_e }}$ from the experimental data for concrete members, which was later experimentally changed to a more accurate TA model - Triantafillou \& Antonopoulos [16]). The ACl uses $\varepsilon_{\text {fro } p_{e}}=\kappa_{v} \cdot \varepsilon_{\text {fro }}$ formula, where $\kappa_{v}$ is the bond reduction coefficient for shear-controlled failure modes, and depends on the FRP reinforcement index $\omega_{f}$ It was obtained experimentally. CNR uses the experimentally determined coefficient $c_{1}$ in the calculation of the specific fracture energy and through that the effective or design strain. For that purpose Wang uses the experimentally determined coefficient $\xi$. Marcari uses experimentally obtained strains in $\operatorname{FRP}\left(\varepsilon_{\text {frp }}\right)$.

\subsection{Triantafillou and Antonopoulos model}

Triantafillou [3] model is suitable for walls that are strengthened horizontally, while vertical reinforcement is neglected in the calculations. Following EC6 for URM the Triantafillou formula for the sum of the uncracked masonry shear strength $V_{R d 1}$ and the effect of shear reinforcement $\mathrm{V}_{R d 2}$ modelled by truss analogy, can be expressed in the following way:

$V_{R d}=V_{R d 1}+V_{R d 2}$

$V_{R d}=\frac{f_{v k} \cdot t \cdot d}{\gamma_{M}}+V_{R d 2} \leq \frac{0.3 \cdot f_{k} \cdot t \cdot d}{\gamma_{M}}$
The characteristic shear strength $f_{v k}$ is expressed by the following equation:

$$
\begin{gathered}
f_{v k}=\min \left(f_{v k 0}+0.4 \cdot \frac{N_{R d}}{l \cdot t}, 0.7 \cdot f_{v k . l i m}, 0.7 \cdot \max \left(0.065 \cdot f_{b}, f_{v k 0}\right)\right) \\
\min \left(f_{v k 0}+0.4 \cdot \frac{N_{R d}}{l \cdot t}, f_{v k . \max }\right)
\end{gathered}
$$

The factor 0.7 has to be applied only in case of seismic design. The contribution of FRP reinforcement to the shear capacity is associated with the action of horizontal FRP reinforcement:

$V_{R d 2}=\frac{0.7}{\gamma_{f r p}} \cdot \rho_{h} \cdot E_{f r p} \cdot \varepsilon_{f r p . e} \cdot l \cdot t$

The partial safety factor for FRP $\gamma_{f r p}$ depends on the type of fibres: 1.15 for CFRP, 1.20 for AFRP, and 1.25 for GFRP. The determination of the effective strains of FRP $\left(\varepsilon_{f r p_{e}}\right)$ is adopted from the Triantafillou \& Antonopoulos [16] model:

$\varepsilon_{\text {frp.e }}=\min \left[0.65\left[\frac{\left(f_{m}\right)^{\frac{2}{3}}}{E_{f r p} \cdot \rho_{h}}\right]^{0.56} \cdot 0.001,0.17\left[\frac{\left(f_{m}\right)^{\frac{2}{3}}}{E_{f r p} \cdot \rho_{h}}\right]^{0.3} \cdot \varepsilon_{f r p . u}\right]$

\subsection{ACl 440.7R-10 (2010)}

In $\mathrm{ACl}$ guide, the contribution of FRPs strengthening in case of the shear controlled failure modes is determined through the bond reduction coefficient $\kappa_{v^{\prime}}$ which was calibrated based on experimental data from different researchers. $\mathrm{ACl}$ code is suitable for calculation of shear load on walls strengthened horizontally and vertically. The nominal lateral strength of URM walls is determined as the lowest of: $V_{b j s}$ the nominal lateral strength corresponding to joint sliding, $V_{d t}$ the nominal lateral strength corresponding to diagonal tension, or $V_{t c}$ the nominal lateral strength corresponding to toe crushing.

$$
\begin{aligned}
& V_{n . S}=V_{n . U R M}+V_{f} \\
& V_{n . U R M}=\min \left(V_{b j s}, V_{d t}, V_{t c}\right) \\
& V_{b j s}=v_{m L} \cdot A_{n} \\
& v_{m L}=0.75 \cdot \frac{0.75 \cdot v_{t L}+\frac{P_{D}}{A_{n}}}{1.5} \\
& V_{d t}=f_{d t} \cdot A_{n} \frac{L}{h_{e f f}} \sqrt{1+\frac{f_{a}}{f_{d t}}} \\
& f_{a}=\frac{P_{D}}{A_{n}} \\
& V_{t c}=\alpha \cdot Q_{G} \cdot \frac{L}{h_{e f f}} \cdot\left(1-\frac{f_{a}}{0.7 \cdot f_{m}}\right) \\
& f_{a}=\frac{Q_{G}}{A_{n}}
\end{aligned}
$$


After computing the nominal shear capacity or nominal lateral strength of the URM wall $V_{n \text {.URM' }}$ the design lateral strength can be computed as $F V_{n . U R M}$. If the design lateral strength is bigger than the factored shear force $V_{u}$ then the wall does not need strengthening for in-plane loads, otherwise it does.

$\Phi \cdot V_{\text {n.URM }}>V_{u}$

The contribution of shear reinforcement with FRP can be presented as follows, where $p_{f v}$ is the total force that can be transferred by the FRP system to the masonry:

$V_{f}=p_{f v} \frac{d_{v}}{s_{f}}$

$d_{v}=\min (H, L)$

$p_{f v}=A_{f} \cdot f_{f e}$

$f_{f e}=E_{f} \cdot \varepsilon_{f e}$

Effective stresses are dependent on effective strains, a function of $k_{v}$ and ultimate rupture strain of the FRP reinforcement as reported by the manufacturer.

$\varepsilon_{f e}=\kappa_{v} \cdot \varepsilon_{f u}$

$$
\begin{array}{ccc}
\kappa_{v}=0.4 & \text { ako je } & \omega_{f} \leq 0.2 \\
\kappa_{v}=0.64-1.2 \cdot \omega_{f} & \text { ako je } & 0.2<\omega_{f} \leq 0.45 \\
\kappa_{v}=0.1 & \text { ako je } & \omega_{f}>0.45
\end{array}
$$

$\omega_{f}=\frac{1}{85} \cdot \frac{A_{f} \cdot E_{f}}{A_{n} \sqrt{f_{m}}}$

When the design lateral shear strength of the FRP strengthened wall is greater than the lateral strength due to toe crushing of the unreinforced wall, a check needs to be performed to ensure that the flexural FRP reinforcement prevents the rupture of the wall due to toe crushing. The maximum lateral force $V_{n, f}$ the wall can sustain before flexural failure is computed as follows:

$V_{n . f}=\frac{M_{n}}{k \cdot h_{e f f}}$

The nominal moment capacity $M_{n}$ of a FRP-strengthened masonry wall subjected to in-plane loading can be calculated as:

$$
M_{n}=\sum_{i}\left[F_{i} \cdot\left(d_{i}-\frac{\beta_{1} \cdot c}{2}\right)\right]+P_{u} \cdot\left(\frac{L}{2}-\frac{\beta_{1} \cdot c}{2}\right)
$$

The nominal lateral strength of a FRP strengthened wall is obtained as the minimum of the nominal shear strength and strength corresponding to flexural failure:

$V_{n}=\min \left(V_{n . s}, V_{n . f}\right)$

\subsection{CNR-DT 200/2004}

The lateral strength of the FRP strengthened walls is computed as the sum of masonry and FRP shear contribution, but failure of the wall can also occur at $V_{\text {Rdmax }}$ (masonry load bearing capacity in the direction of compressive stresses). The value of $f_{v k}$ has to be determined in compliance with the current building code which is EC 6 (same as Triantafillou - Equation 3). No information is provided in CNR DT200 for masonry walls strengthened with inclined FRP strips,

$V_{R d}=\min \left(V_{R d . m}+V_{R d . f}, V_{R d \max }\right)$

$V_{R d . m}=\frac{1}{\gamma_{R d}} \cdot d \cdot t \cdot f_{v d}$

$f_{v d}=\frac{f_{v k}}{\gamma_{M}}$

$V_{R d . f}=\frac{1}{\gamma_{R d}} \cdot \frac{0.6 \cdot d \cdot A_{f w} \cdot f_{f d}}{p_{f}}$

$f_{f d}=E_{f} \cdot \varepsilon_{f d}$

$\varepsilon_{f d}=\min \left(\eta_{a} \cdot \frac{\varepsilon_{f k}}{\gamma_{f}}, \varepsilon_{f d d}\right)$

$\varepsilon_{f d d}=\frac{f_{f d d}}{E_{f}}$

$f_{f d d}=\frac{1}{\gamma_{f . d} \cdot \sqrt{\gamma_{M}}} \cdot \sqrt{2 \cdot \frac{E_{f} \cdot \Gamma_{F k}}{t_{f}}}$

$\Gamma_{F k}=c_{1} \cdot \sqrt{f_{m k} \cdot f_{m t m}}$

$V_{\text {Rdmax }}=0.3 \cdot f_{\text {md.h }} \cdot t \cdot d$

The partial factor for the resistance model $\gamma_{R d}$ is 1.2 for shear, and $c_{1}$ is the empirically determined coefficient equal to 0.015 .

\subsection{Wang et al.}

Wang [17] proposed formulas for masonry walls reinforced with horizontal, diagonal, or combined diagonal and horizontal sheets.

$V_{u}=V_{w}+V_{f r p}$

The equation from EC6 was adopted for the load bearing capacity of URM walls in case of sliding shear failure:

$f_{v}=f_{v 0}+0.4 \cdot \sigma_{v}$

and, for diagonal cracks failure, the conventional formula from the principal tensile stress theory was modified by adding the statistical coefficient 2.1, which was obtained by statistical analysis of correlative data from many universities:

$f_{v}=\frac{f_{v 0}}{1.2} \sqrt{1+2.10 \cdot \frac{\sigma_{v}}{f_{v 0}}}$ 


$$
V_{w}=f_{v} \cdot A_{0}
$$

The designed shear contribution provided by FRP sheets is expressed as:

$V_{f r p_{-} d}=E_{f} \cdot \varepsilon_{u} \cdot\left[\xi_{s} \cdot n_{s} \cdot A_{f s}+\xi_{x} \cdot n_{x} \cdot A_{f x} \cdot(\cos \Theta+0.2 \cdot \sin \Theta)\right]$ (39)

$\xi_{s}=-0.245 \cdot \ln (\rho)-0.128$

$\xi_{x}=-0.411 \cdot \ln (\rho)-0.107$

where the index "s" stands for horizontal and index " $x$ " for inclined contribution.

\subsection{Marcari et al.}

Marcari [6] presented a calculation model for calculating shear walls strengthened with inclined strips. The shear strength is the sum of the shear strength of masonry computed for the increased vertical load $N_{0}+N_{m, f r p}$ and the FRP contribution to shear capacity:

$V_{S M}=\min \left(V_{\text {m.diag.shear }}+V_{\text {frp }}, V_{\text {m.flexural }}\right)$

For masonry contribution, the diagonal shear and rocking failure are taken under consideration. The equation for bed joint sliding was not presented and it was neglected because no experimental evidence of sliding failure was detected in this case. The diagonal tension shear strength is computed using the shear strength formulation originally derived by Turnšek and Čačovič [29]:

$V_{\text {m.diag.shear }}=B \cdot t \cdot \frac{1.5 \cdot \tau_{0 d}}{b} \sqrt{1+\frac{\sigma_{0}}{1.5 \cdot \tau_{0 d}}}$

$b=\frac{H}{B} \quad 1 \leq b \leq 1.5$

$\sigma_{0}=\frac{N}{A}$

The maximum shear associated to flexural mechanism:

$V_{m . \text { flexural }}=\psi \cdot \frac{B^{2} \cdot t}{H} \cdot \frac{\sigma_{0}}{2} \cdot\left(1-\frac{\sigma_{0}}{0.85 \cdot f_{m}}\right)$

The strength of masonry is computed for the increased vertical load $N_{0}+N_{m, f r p}$ due to truss mechanism.

$N=\max \left(N_{0}+N_{m . f r p}\right)$

$N_{m . f r p}=F_{f r p} \cdot \sin (\theta)$

$F_{f r p}=n \cdot\left(E_{f r p} \cdot w_{f r p} \cdot t_{f r p}\right) \cdot \varepsilon_{f r p}$

$V_{f r p}=F_{f r p} \cdot \cos (\theta)$

\section{List of symbols}

\begin{tabular}{|c|c|}
\hline$A$ & gross section area of the wall (Marcari) \\
\hline$A_{0}$ & wall horizontal cross section (Wang) \\
\hline$A_{f s}$ & cross section of FRP in horizontal direction \\
\hline$A_{f w}$ & FRP effective cross section \\
\hline$A_{f x}$ & cross section of FRP in inclined direction \\
\hline$A_{n}$ & wall horizontal cross section (ACI) \\
\hline$B$ & base, length of the panel \\
\hline$E_{f}$ & modulus of elasticity of FRP reinforcement ( $\mathrm{ACl}$; Wang, CNR) \\
\hline$E_{\text {frp }}$ & $\begin{array}{l}\text { modulus of elasticity of FRP reinforcement } \\
\text { (Triantafillou, Marcari) }\end{array}$ \\
\hline$F_{\text {frp }}$ & tensile force in the diagonal plies \\
\hline$F_{i}$ & force acting on the i-th FRP strip \\
\hline$H$ & height of the panel \\
\hline$L$ & length of the wall \\
\hline$M_{n}$ & nominal flexural strength \\
\hline$N$ & vertical load \\
\hline$N_{0}$ & average pre-compression load \\
\hline$N_{m . f r p}$ & $\begin{array}{l}\text { increased vertical load carried through masonry on } \\
\text { account of FRP }\end{array}$ \\
\hline$N_{R d}$ & axial force \\
\hline$P_{D}$ & design dead load \\
\hline$P_{u}$ & $\begin{array}{l}\text { factored axial load as a resultant of uniformly } \\
\text { distributed load acting on the wall }\end{array}$ \\
\hline$Q_{G}$ & design gravity load \\
\hline$V_{b j s}$ & shear strength corresponding to bed joint sliding \\
\hline$V_{d t}$ & shear strength corresponding to diagonal tension \\
\hline$V_{f}$ & FRP contribution to shear strength of masonry (ACI) \\
\hline$V_{f r p}$ & FRP contribution to the shear strength (Wang, Marcari) \\
\hline$V_{\text {frp_d }}$ & designed shear contribution of FRP \\
\hline$V_{\text {m.diag.shear }}$ & diagonal tension shear strength of masonry \\
\hline$V_{n}$ & nominal lateral strength of the FRP-strengthened wall \\
\hline$V_{n . f}$ & $\begin{array}{l}\text { shear strength corresponding to flexural failure of the } \\
\text { FRP-strengthened wall }\end{array}$ \\
\hline$V_{n . s}$ & shear strength of strengthened masonry (ACI) \\
\hline$V_{\text {n.URM }}$ & shear strength of URM (ACI) \\
\hline$V_{R d}$ & $\begin{array}{l}\text { shear strength of strengthened masonry (Triantafillou, } \\
\text { CNR) }\end{array}$ \\
\hline$V_{R d 1}$ & shear strength of masonry (Triantafillou) \\
\hline$V_{R d 2}$ & $\begin{array}{l}\text { FRP contribution to shear strength of masonry } \\
\text { (Triantafillou) }\end{array}$ \\
\hline$V_{\text {Rd.f }}$ & FRP contribution to shear strength of masonry (CNR) \\
\hline$V_{R d . m}$ & masonry shear strength (CNR) \\
\hline$V_{\text {Rdmax }}$ & compressive strength limit \\
\hline$V_{S M}$ & shear strength of strengthened panel (Marcari) \\
\hline$V_{t c}$ & shear strength corresponding to toe crushing \\
\hline$V_{u}$ & factored shear force \\
\hline$V_{w}$ & masonry shear strength (Wang) \\
\hline
\end{tabular}




\begin{tabular}{|c|c|}
\hline$b$ & ratio of the height to the length of the wall $\mathrm{H} / \mathrm{B}$ \\
\hline$c$ & $\begin{array}{l}\text { distance from the fiber of maximum compressive strain to } \\
\text { the neutral axis }\end{array}$ \\
\hline$c_{1}$ & empirically determined coefficient (0.015) \\
\hline$d$ & effective depth of masonry wall ( ) (Triantafillou, CNR) \\
\hline$d_{i}$ & $\begin{array}{l}\text { distance of force Fi measured from the extreme } \\
\text { compression fiber }\end{array}$ \\
\hline$d_{f}$ & $\begin{array}{l}\text { distance between the compression side of the masonry } \\
\text { and the centroid of FRP flexural strengthening }\end{array}$ \\
\hline$d_{v}$ & effective masonry depth for shear calculations (ACI) \\
\hline$f_{a}$ & axial compressive stress due to gravity loads \\
\hline$f_{b}$ & normalised compressive strength of masonry units \\
\hline$f_{d t}$ & specified masonry diagonal tension strength \\
\hline$f_{f d}$ & design strength of FRP reinforcement \\
\hline$f_{\text {fdd }}$ & design debonding strength of FRP reinforcement \\
\hline$f_{f e}$ & effective stress level in the FRP reinforcement \\
\hline$f_{k}$ & $\begin{array}{l}\text { characteristic compressive strength of masonry } \\
\text { (Triantafillou) }\end{array}$ \\
\hline$f_{m}$ & compressive strength of masonry (ACI) \\
\hline$f_{m d . h}$ & $\begin{array}{l}\text { design compressive strength of masonry in the horizontal } \\
\text { direction }\end{array}$ \\
\hline$f_{m k}$ & characteristic compressive strength of masonry (CNR) \\
\hline$f_{m t m}$ & mean value of tensile strength of masonry \\
\hline$f_{\mathrm{v}}$ & characteristic shear strength of masonry (Wang) \\
\hline$f_{\mathrm{vo}}$ & $\begin{array}{l}\text { characteristic shear strength of masonry under zero } \\
\text { compressive stress }\end{array}$ \\
\hline$f_{v d}$ & design shear strength of masonry \\
\hline$f_{v k}$ & $\begin{array}{l}\text { characteristic shear strength of masonry (Triantafillou, } \\
\text { CNR) }\end{array}$ \\
\hline$f_{v k 0}$ & shear strength of masonry under zero compressive stress \\
\hline$f_{v k \text { lim }}$ & limiting value of $f_{v k}$ \\
\hline$f_{\text {vk.max }}$ & maximum value of $f_{v k}$ \\
\hline$h_{\text {eff }}$ & height to resultant of lateral force \\
\hline$k$ & $\begin{array}{l}\text { coefficient accounting for the boundary conditions of } \\
\text { the wall }\end{array}$ \\
\hline I & length of the wall \\
\hline$n$ & FRP ply number \\
\hline$n_{s}$ & number of horizontal FRP strips \\
\hline$n_{x}$ & number of inclined FRP strips \\
\hline$p_{f}$ & spacing of FRP strips \\
\hline$s_{f}$ & $\begin{array}{l}\text { centre-to-centre spacing of FRP reinforcement } \\
\text { measured perpendicular to the direction of shear force }\end{array}$ \\
\hline
\end{tabular}

\subsection{Comparison of calculated and experimental values}

In Figure 20, the results of experimental tests (presented as lines) are compared with calculation results obtained by different authors (bars). The dotted line is the experimentally obtained result for the un-reinforced masonry only, while

\begin{tabular}{|c|c|}
\hline$t$ & thickness of the wall panel \\
\hline$t_{f}$ & thickness of FRP strip \\
\hline$t_{\text {frp }}$ & thickness of the diagonal ply \\
\hline$w_{\text {frp }}$ & width of the diagonal ply \\
\hline$\Gamma_{F k}$ & characteristic value of specific fracture energy \\
\hline$\lambda$ & $\begin{array}{l}\text { factor equal to } 0.5 \text { for fixed-free cantilever wall, or } \\
\text { equal to } 1.0 \text { for fixed-fixed wall pier }\end{array}$ \\
\hline$\beta_{1}$ & $\begin{array}{l}\text { ratio of the depth of the equivalent rectangular stress } \\
\text { block to neutral axis }\end{array}$ \\
\hline$\gamma_{f}$ & partial material safety factor for FRP rupture \\
\hline$\gamma_{f . d}$ & partial material safety factor for FRP debonding \\
\hline$\gamma_{\text {frp }}$ & partial safety factor for FRP \\
\hline$\gamma_{M}$ & partial material safety factor \\
\hline$\gamma_{R d}$ & partial safety factor for resistance model \\
\hline$\varepsilon_{f d}$ & design (effective) strain of FRP reinforcement (CNR) \\
\hline$\varepsilon_{\text {fdd }}$ & maximum strain of FRP reinforcement (CNR) \\
\hline$\varepsilon_{f e}$ & effective strain in FRP reinforcement (ACI) \\
\hline$\varepsilon_{f k}$ & FRP characteristic strain at failure (CNR) \\
\hline$\varepsilon_{\text {frp }}$ & FRP strain (Marcari) \\
\hline$\varepsilon_{t p p e}$ & effective FRP strain (Triantafillou) \\
\hline$\varepsilon_{t p p u}$ & ultimate tensile strain of FRP (Triantafillou) \\
\hline$\varepsilon_{f u}$ & design rupture strain of the FRP reinforcement (ACI) \\
\hline$\varepsilon_{u}$ & ultimate FRP strain (Wang) \\
\hline$\eta_{a}$ & environmental conversion factor \\
\hline$\theta$ & angle of tensile diagonal to horizontal direction \\
\hline$\kappa_{v}$ & $\begin{array}{l}\text { bond reduction coefficient for shear-controlled failure } \\
\text { modes }\end{array}$ \\
\hline$v_{m L}$ & lower-bound masonry shear strength \\
\hline$v_{t L}$ & lower-bound bed-joint shear strength \\
\hline$\xi_{s}$ & effective working coefficient of horizontal FRP sheet \\
\hline$\xi_{x}$ & effective working coefficient of diagonal FRP sheet \\
\hline$\rho$ & area reinforcement rate of FRP \\
\hline$\rho_{h}$ & $\begin{array}{l}\text { ratio of FRP reinforcement cross section to masonry } \\
\text { cross section }\end{array}$ \\
\hline$\sigma_{0}$ & average stress in the gross section area \\
\hline$\sigma_{v}$ & compressive stress due to vertical load \\
\hline$\tau_{0 d}$ & the diagonal shear strength of masonry \\
\hline$\phi$ & strength reduction factor \\
\hline$\psi$ & parameter which describes boundary conditions \\
\hline$\varpi_{f}$ & FRP reinforcement index \\
\hline
\end{tabular}

the solid line represents the horizontal load bearing capacity of a wall strengthened with FRP. Calculated contribution of URM for each tested configuration is in light shade, while FRP contribution is in dark grey. The presented columns in charts are numerically obtained results, where a different approach is used in each calculation model to determine failure modes (and not all modes are present in each model). 

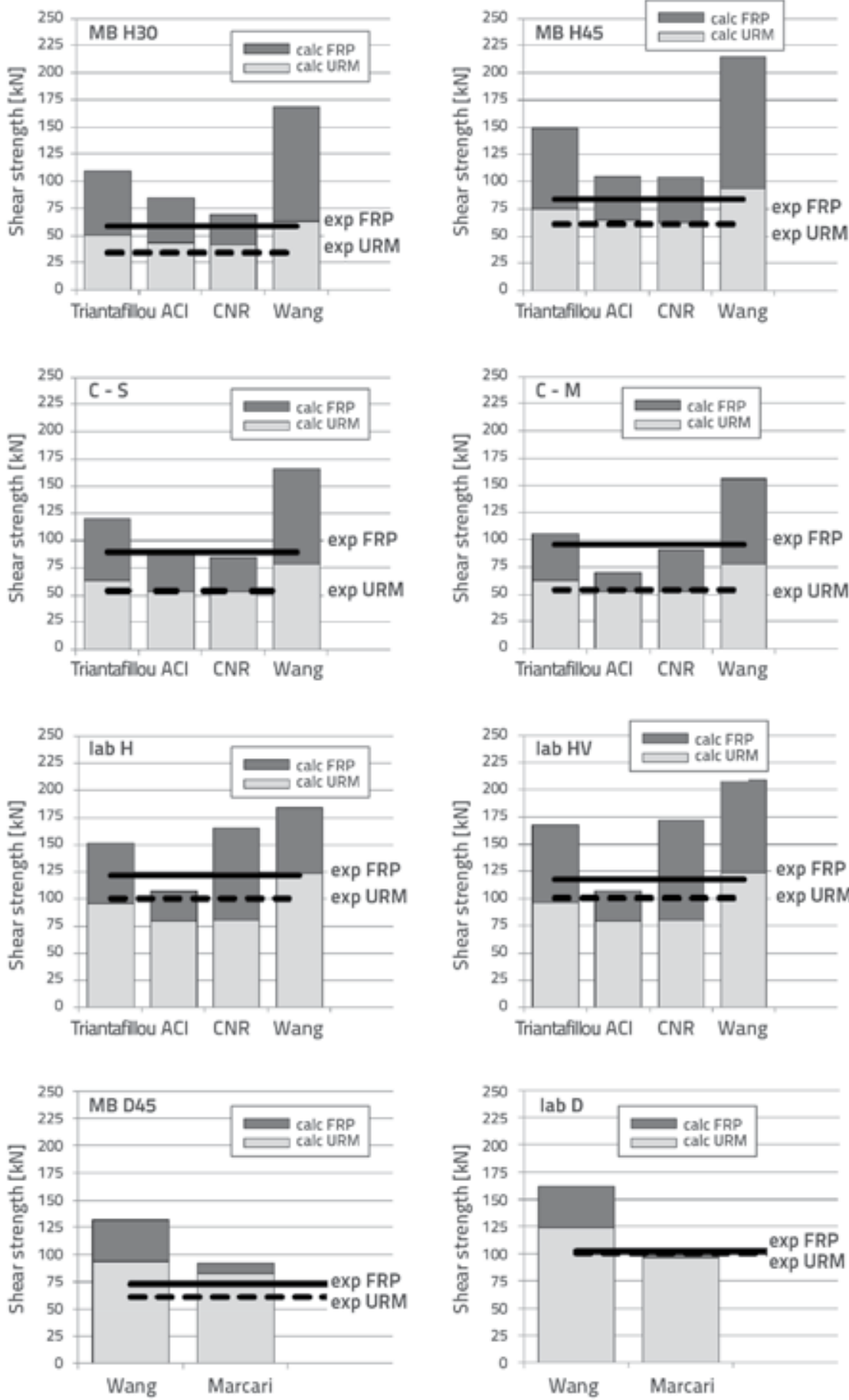

Figure 20. Comparison of masonry shear strength and contribution of FRP strengthening by different authors for the set of performed tests

For this reason, the actual failure modes are not necessarily consistent with the predicted modes while the shear strength might be calculated correctly. Different failure modes were observed during our experiments. The failure of diagonal strips was always due to detachment from the masonry surface (in laboratory and in-situ) The failure mode for laboratory testing of masonry confined with strips showed predominantly crushing of the compressed toe (along with diagonal cracking) where strips were acting as a sort of ties. During in-situ tests, the failure mode was more of (diagonal) shear with propagation of diagonal cracks due to tensile stresses in the middle of the wall. But the failure occurred when deformations, and therefore load, could not be transferred anymore from masonry to FRP. Although strips were not visibly detached from the masonry surface, the maximum capacity of the FRP - masonry connection was limited by the effective relative deformation. It can be said that the capacity was exhausted when deformations from the masonry (due to internal cracking) could no longer be transferred to strips. So the calculated effective relative deformations are the maximum possible developed deformations of the composite system (FRP with masonry) as proposed by authors. It can be concluded that it is important to have proper anchorage of FRP reinforcement to achieve of the full in-plane strength of the walls. A proper anchorage was achieved by wrapping strips around the wall pier.

The Triantafillou model starts with quite a good definition of the un-reinforced masonry contribution, especially in case of relatively strong masonry walls, tested in laboratory ( $4 \%$ on conservative side). For the samples tested in-situ (they were quite weak), the model overestimates the contribution of the masonry shear capacity by 26 $\%$. The final load bearing capacity of strengthened walls is overestimated in most cases, and ranges from $10 \%$ (C-M) to $85 \%$ (MB45). Weaker reinforcing material is evaluated better. Triantafillou is accurate in predicting failure mechanisms for weak walls, but not for strong walls. For strong walls, a toe crushing prediction at $30 \%$ of masonry compressive strength appears to be too high or not well defined.

The CNR model is a bit more conservative at calculating the URM contribution. It is quite accurate in the case of relatively weak walls (5\% over experimental values) and 
underestimating for the strong walls (20\% below experiment). Triantafillou and CNR models are using the EC 6 definition for unreinforced masonry walls where the masonry joint sliding is assumed as critical mechanism for the shear strength wall subjected to a horizontal force. CNR results for shear strength for URM are more conservative because the characteristic value of the shear strength $f_{v k}$ is divided by a partial factor for the resistance model $\gamma_{R d^{*}}$. The shear strength of the reinforced specimen calculated by the CNR is close to the experimentally obtained in the case of weak walls (in-situ tests; $7 \%$ overestimated) but, unfortunately in some cases (in-situ MB) it did not correspond to the actual failure mechanisms observed in the tests. For insitu $C$ the failure mechanisms were predicted correctly. In the case of strong walls, the FRP contribution and diagonal compressive strength are both overestimated resulting in $41 \%$ overestimation. Comparing CNR to Triantafillou showed toe crushing at $15 \%$ of compressive strength, which is a half of the Triantafillou proposition. The actual performance is somewhere in between - closer to lower value for strong walls and up to $25 \%$ of compressive strength for weak walls.

The $\mathrm{ACl}$ calculation model gives almost the same results as the CNR for the contribution of plain masonry to the shear load capacity. It is accurate in case of relatively weak walls (7 $\%$ overestimation) and $20 \%$ underestimating for the strong walls. The $\mathrm{ACl}$ is quite good for the failure mode prediction except for a low vertical load (under $10 \%$ of compressive strength), when toe-crushing numerically occurs, contrary to what was observed during the experiments (diagonal cracks). In this case, a careful evaluation of results is needed, because for moderate level of pre-compression, the bed joint sliding should prevail over toe-crushing. The ACl approach for toe-crushing prediction contains more aspects than the CNR or Triantafillou approach. It is dependent on the actual load, compressive strength, effective height of the specimen, and other factors, not only on compressive strength. $\mathrm{ACl}$ also assumes both diagonal tension failure and bed joint sliding as possible failure of specimens at shear loading, not only the bed joint sliding as proposed by CNR and Triantafillou. This is decisive for walls with a higher vertical load, where diagonal tension might be dominant. According to $\mathrm{ACl}$ approach, the joint sliding was decisive in case of in-situ walls with low preload. Numerically, the difference between the slide and diagonal tension failure is approximately $50 \%$ for walls in laboratory (due to high vertical load), while there is almost no difference for in-situ walls with a low vertical load. Overall, on an average, the $\mathrm{ACl}$ is closest to experimental results for all tested walls, both for URM ( $2 \%$ underestimation) and FRP strengthened walls ( $4 \%$ overestimation).

The Wang model [5] estimates the URM (unreinforced masonry) shear capacity much higher when compared to the results of in-situ tests ( $58 \%$ overestimation) and laboratory tests ( $23 \%$ overestimation). Wang assumes bed joint sliding (model from EC6) and diagonal tension failure as possible failure mechanisms under shear loading. But it does not control the possibility of toe-crushing. Even though in Wang's formula the coefficients for diagonal tension failure are statistically obtained, the results highly overestimated our experimental values (for $54 \%$ ). The diagonal tension failure was decisive for strong walls in laboratory, though for weak walls the slide and diagonal tension failure occurred at the same time. The calculated load bearing of walls including FRP contribution was overestimated in all cases (from $52 \%$ to $185 \%$ ).

The Marcari [6] approach is quite accurate for URM contribution to shear strength of good walls $(4 \%$ underestimate) while for weak walls the values are overestimated by $36 \%$. The load bearing capacity of the strengthened walls is overestimated by $26 \%$ for the weak wall (D45), and is very close (1\%) for the laboratory $D$ case. Only the diagonal shear is taken into consideration for masonry contribution. The bed joint sliding was neglected in the original Marcari model because no experimental evidence of sliding failure was detected. No formula for bed joint sliding has been proposed for calculation purposes. Our test results, similarly to Marcari, showed no failure by joint sliding. The flexural failure was also checked, but it was not decisive in our cases, which is consistent with test results. The formula for toe-crushing is similar to that proposed in $\mathrm{ACl}$. Predicted failure mechanisms in both our cases are unfortunately opposite to what actually occurred. The decision to use or not to use both formulae for bed joint sliding and diagonal tension failure for calculating the URM contribution is the decisive difference between calculation models. It is also very important how the flexural toe crushing mechanism is verified. In case of weak walls the results also differ because of other factors. The biggest influence is how a participating cross-section of the specimen is defined (the length of specimen). CNR and Triantafillou defined effective depth as $80 \%$ of the masonry wall length, while Wang includes the complete net area in calculation. This difference provides $20 \%$ higher shear strength of URM for Wang model compared to Triantafillou. The shear strength limitation boundary predicted by EC 6 (used by CNR and Triantafillou) is important for strong walls. If the URM strength is predicted too high, then the final shear strength of strengthened elements might be exaggerated. $\mathrm{ACl}$ and CNR are mostly on the safe side for calculation of URM. The results of Triantafillou were a little higher, and results by Wang were highly overestimated for our set of experimental data. Limitation of the diagonal compression strength might also lead to an overestimation of shear performance of the walls (Wang). In calculations, the toe-crushing failure mechanism was often a governing behaviour, especially when diagonal or bed sliding mechanisms (usual for URM) were postponed due to the use of FRP. 


\section{Conclusion}

Two sets of in-situ tests (12 specimens) and one set of laboratory tests (16 specimens) under cyclic horizontal load were performed to evaluate the efficiency of FRP surface strengthening with carbon fibre reinforced polymer (CFRP) strips and glass fibre reinforced polymer (GFRP) grids. The results were compared as to the strengthening technique used and in respect to the calculated values, using five different calculation models. The FRP strengthening favourably influenced the mechanism of wall behaviour in all cases. The biggest increase in shear strength (approx. $170 \%$ ) was obtained by horizontal strengthening of the (weak) walls on site. The effect of horizontal strengthening on the laboratory walls was $120 \%$. The highest increase of ultimate rotation (380\%) can be noticed for horizontal (and vertical) CFRP strips of fabric which strengthened masonry on site, and it was also high (around $200 \%$ ) for configurations $\mathrm{H}$ and HV tested in the laboratory. The failure mechanism of in-situ specimens was mostly due to diagonal tension failure. Laboratory specimens failed by crushing of the compression toe combined with diagonal cracking. Horizontal FRP strips did not detach from the surface because they were well connected around the masonry pier. Strips in diagonal configuration did not perform so well. Diagonal FRP configuration contributes marginally to shear strength ( $\sim \%$ ) and with about $10 \%$ to ultimate rotation. The in-situ tests for diagonal configurations were governed by peeling of the strips from the masonry, but the toecrushing failure was decisive for laboratory test. When using GFRP grid in a modified cement mortar for strengthening the load bearing capacity for in-plane the shear was almost doubled though its behaviour was non-ductile, i.e. similar to an un-reinforced wall. The failure mechanism was due to the detachment of coating from the wall surface.

The quality of basic masonry material had a significant impact on the behaviour of reinforced specimens. Better strengthening results were obtained on initially weaker (old) masonry. The best results (in terms of load bearing and deformation capacity) were obtained for the walls strengthened with horizontal strips. The combination with vertical strips did not influence the results to a great extent. In terms of strength, the best strengthening method was the one involving the GFRP grid. The contribution of diagonal strips to shear strength and ultimate rotation of strengthened wall was, on average, negligible.

Five different calculation models for determining shear strength of FRP strengthened masonry walls are presented in this paper: Triantafillou [16], Wang [17] and Marcari [18], and two design guides: ACl 440.7R-10 (2010) and CNR-DT 200/2004). The accuracy of each approach was assessed through comparison with the experimental results. ACland CNR calculation models provided values closest to experimental results, except for FRP contribution for strong (laboratory) walls in case of CNR. Approaches of Triantafillou and Wang give excessively high values for the shear load capacity. Triantafillou slightly overestimates masonry contribution for weak walls, and highly overestimates FRP contribution, while in Wang's case both values are highly overestimated. Marcari approach is quite accurate for URM contribution for strong walls while for weak walls it overestimates the URM shear strength. However, the FRP contribution (small in our experiments) is predicted correctly. Experimentally observed failure modes corresponded quite well to the predicted failure modes in the case of $\mathrm{ACl}$, although in other procedures the determination of failure modes is less accurate.

Each calculation model uses different approach for determining the shear strength and failure modes that define it. Because of that, the actual failure modes were not necessarily consistent with the predicted mechanisms although the shear strength might have been calculated correctly. There is a difference between the way in which models calculate URM contribution - considering only bed joint sliding or/and diagonal tension failure. In addition, the final result is influenced by other boundaries and limiting values (participating cross-section of the wall, shear strength limitation boundary, etc). It is important to calculate URM strength accurately as excessively high results might result in misleading values when calculating final shear strength of strengthened elements. A proper definition of effective strain before FRP detachment from the masonry is crucial for calculating the FRP contribution. A rupture failure of FRP was not registered in our experiments. A limitation by the diagonal compression strength of the masonry is also important for the strengthened walls, because the usual failure mechanisms of URM (diagonal tension failure or bed joint sliding) often change to diagonal compressive failure of FRP strengthened elements.

The comparison of experimental and analytical results shows a considerably large scattering. The quantity of tests performed in the scope of this study does not allow us to completely validate calculation models as such validation would require a greater number of experiments. However, the analysis of calculation models shows a trend for possible expected results.

\section{Acknowledgements}

The results of in-situ tests were obtained in scope of the project PERPETUATE (www.perpetuate.eu), funded by the European Commission through the Seventh Framework Programme (FP7/2007-2013), under grant agreement $n^{\circ}$ 244229.

The results of laboratory tests were funded by the Ministry of Higher Education, Research and Technology of the Republic of Slovenia under grant no. Z2-3411. 


\section{REFERENCES}

[1] Croci, G., D'Ayala, D., D'Asdia, P., Palombini, F.: Analysis on shear walls reinforced with Fibers, IABSE Symp. On Safety and Quality Assurance of Civ. Engrg. Struct., Int. Assoc. For Bridge and Struct., Lisbon, Portugal, 1987

[2] Schwegler, G.: Masonry constriction strengthened with fiber composites in seismically endangered zones Proc., 10th Europ. Conf. On Earthquake Engineering, A. A. Balkema, Rotterdam, The Netherlands, 454-458, 1994.

[3] Triantafillou, T.C.: Strengthening of Masonry Structures Using Epoxy- Bonded FRP Laminates, Journal of Composites for Construction, Vol. 2, Iss. 2., 1998.

[4] Ehsani, M.R., Saadatmanesh, H.: Shear behaviour of URM retrofitted with FRP overlays, Journal of composites for construction, pp. 17-25, 1997.

[5] Borri, A., Corradi, M., Vignoli, A.: Seismic upgrading of masonry structures with FRP, 7th International Conference on inspection appraisal repairs and maintenance of buildings and structures, Notthingam Trent University, Nottingham, United Kingdom, pp. 43-54, 2001.

[6] Valluzi, M.R., Tinazzi, D., Modena, C.: Shear behavior of masonry panels strengthened by FRP laminates, Construction and Building materials, 16, pp. 409-416, 2002.

[7] Santa-Maria, H., Duarte, G., Garib, A.: Experimental investigation of masonry panels externally strengthened with CFRP laminates and fabric subjected to in-plane shear load, 8th U.S. National Conference on Eartquake Engineering, San Francisco, USA, Paper No.1042, 2004.

[8] Alcaíno, P., Santa María, H.: Shear response of brick masonry walls externally retroffited with bonded carbon fiber fabric, 8th Pacific Conference on Earthquake Engineering, Singapur, 2007.

[9] Gostič, S., Mezgec, A., Žarnić, R.: Študija učinkovitosti naprednih metod za sanacijo zidanih stavb, Raziskovalni projekt MŠZŠ Z23411, 2004

[10] Galić. J., Sorić, Z., Rak, M.: Ojačavanje posmično opterećenih zidanih zidova, Gradevinar, volumen 59, broj 4, pp. 289-299, 2007.

[11] Španić, M., Hadzima-Nyarko, M., Morić, D.: Ojačanje povijesnih građevina kompozitnim polimerima, e-gfos, broj 5, pp. 74-85, 2012.

[12] ElGawady, M.; Lestuzzi, P., Badoux, M.: In-Plane Seismic Response of URM Walls Upgraded with FRP, Journal of Composites for Construction, Vol. 9, Iss. 6, November/December 2005, pp. 524-535, 2005.

[13] Papanicolaou, C.G., Triantafillou, T.C., Karlos, K., Papathanasius M.: Textile-reinforced mortar (TRM) versus FRP as strengthening aterial of URM walls: in-plane cyclic loading, Materials and structures, 40, pp. 1081-1097, 2006

[14] Triantafillou, T.: Textile-Reinforced Mortars (TRM): A new generation of Composite Materials as Alternative to Fibrereinforced Polymers (FRP) for strengthening and Seismic Retrofitting of Structures, Composite materials, Springer-Verlag London Limited, 2011.
[15] Tomaževič, M., Gams, M., Oblak, A.: Protipotresno utrjevanje opečnih zidov s kompozitnimi oblogami, Gradbeni vestnik, letnik 60, september 2011, pp. 246-257, 2011

[16] Triantafillou, T.C., Antonopoulos, C.P.: Design of concrete flexural members strengthened in shear with FRP, Journal of Composites for Construction, ASCE, 4 (4), pp. 198-205, 2000.

[17] Wang, Q., Chai, Z., Huang, Y., Yang, Y., Zhang Y.: Seismic shear capacity of brick masonry wall reinforced by GFRP, Asian journal of civil engineering (building and housing), Vol. 7, No. 6, pages 563-580, 2006

[18] Marcari, G., Oliveira, D., Fabroccino, G., Lourenço, P. B.: In-plane behaviour of tuff masonry panels strengthened with FRP diagonal layout, The 11th North American Masonry Conference, Minneapolis, Minnesota, USA, 2011

[19] CNR-DT 200/2004, Guide for design and Construction of Externally Bonded FRP systems for Strengthening Existing Structures, Advisory committee on technical recommendations for construction, Rome - CNR July 13th, 2004.

[20] ACl 440.7R-10, Guide for Design \& Constr. of Externally Bonded FRP Systems for Strengthening Unreinforced Masonry Structures, ACI Committee 440, USA, 2010.

[21] Gostič, S., Bosiljkov, V., Jarc Simonič, M.: In-situ testing of brick masonry walls strengthened with CFRP fabric, 15th International Brick and Block masonry Conference, Florianopolis, Brazil, 2012.

[22] Jarc Simonič, M., Gostič, S., Žarnić, R.: In-situ tested brick masonry walls strengthened with horizontal carbon strips and FRP mesh, 12th Canadian masonry Symposium, Vancouver, British Columbia, 2013.

[23] Bosiljkov, V.: Micro vs. macro reinforcement of brickwork masonry, Mat. struct., vol. 39, no. 2, pp. 235-245, 2006.

[24] Garbin, E., Galati, N., Nanni, A., Modena, C., Valluzzi, M.R.: Provisional design guidelines for the strengthening of masonry structures subjected to in-.plane loading, North American masonry Conference, St. Louis, Missouri, USA, 2007.

[25] Prota, A., Manfredi, G., Nardone F.: Assessment of Design Formulas for In-Plane FRP Strengthening of Masonry Walls, Journal of composites for construction, ASCE, Vol. 12:6, pp. 643649, 2008.

[26] Zhuge, Y.: FRP-Retrofitted URM Walls under In-Plane Shear: Review and Assessment of Available Models, Journal of Composites for Construction, Vol14, No. 6, 2010.

[27] Myers, J.J.: Strengthening unreinforced masonry structures using externally bonded fiber reinforced polymer systems: An overview of the American concrete institute 440.7R design approach, 9th Australasian masonry Conference, Queenstown, New Zealand, 2011.

[28] Nardone, F., Prota A., Manfredi, G.: Design criteria for FRP seismic strengthening of masonry walls, The 14th World Conference on Earthquake Engineering, Beijing, China, 2008.

[29] Turnšek, V., Čačovič F.: Some Experimental Results on the Strength of Brick Masonry Walls, Proceedings to 2nd International Brick Masonry Conference, Stoke-on-Trent, U.K., pp. 149-156, 1971 